\title{
ARPAの性能を向上させるレーダ信号処理について
}

$\begin{array}{lll}\text { 小塚 } & \text { 孝徳 } \\ \text { ・ 林 尚吾** } \\ \text { 外岡 幸吉***竹内 毅**** }\end{array}$

\section{Radar Signal Processing Improving Performance of ARPA}

Takanori KOZUKA, Shogo HAYASHI, Koukichi SOTOOKA and Tsuyoshi TAKEUCHI

\begin{abstract}
With respect to shipboard radar signal processing, the method of reducing noise by LOG-CFAR circuit system up to now has bad little effect on the scatter of larger amplitude values which signal sea clutter.

Taking the ship's tracking radar as the most important factor, the authors decided to calculate the threshold of the clutter value in order to enhance incoming data that might signal the presence of other ships.

Accordingly, two variables were identified, the value of the average amplitude $\mathrm{N}$ and the indicated scatter deflection variable $\mathrm{D}$. By multiplying each variable ( $\mathrm{k}$ with $\mathrm{N}$ and $\mathrm{m}$ with $\mathrm{D}$ respectively) and adding them together yields the threshold value Th.

$$
T h=k N+m D \text {. }
$$

Such calculations of Th were carried out in other procedures.

In order to ignore the land and sea clutter and to distinguish the presence of other ships, the athors analyzed by statistical methods both pulse and scan correlations.

As a result of the various experiments at sea and from land with these methods, the effect of sea clutter was reduced. The results show improvement in two respects: Although problems remain with ARPA (Automatic Radar Plotting Aids), the ability to distinguish the signals of other ships and the accuracy of tracking their progress by these improvements in signal processing is enhanced.

\section{1.はじめに}

現在使用されているARPAには下記に示す問題がある。

(1) 波浪や海岸線を目標として誤探知したり、シークラッタ等により目標が探知できないことがある。

（2）追尾目標処理可能数を上回る船船が存在する場合、追尾していない他船が自船周囲を航行しても認識 できない。

これらの問題を改善するため他船検出方式や他船を検出すべき領域について検討し性能の向上を図った。
\end{abstract}

\section{2.レーダ信号処理方式の検討}

* 正会員 日本アビオニクス株式会社（テ246 横浜市瀬谷区本郷2-28-2）

** 正会員 東京商船大学 (下135 東京都江東区越中島2-1-6)

*** 正会員 住友重機械工業株式会社（テ237 横須賀市夏島町19）

****非会員 日本アビオニクス株式会社（干246 横浜市瀬谷区本郷2-28-2） 
2.1 しきい值算出方式の検討

2.1 .1 従来のCFAR処理方式の 問題点

目標を検出しようとする船舶レー ダのビデオには海上の他船舶や浮遊 物からの反射の他、海面や陸地から の反射、さらにレーダ受信機雑音が 含まれる。したがって目標検出機能 にはビデオ信号中のクラッタ等を抑 圧してできるだけ海面や陸地からの 反射やレーダ受信機雑音を目標とし て検出することなく、海上の他船舶 や浮遊物のみを検出することが要求 される。

レーダビデオから船舶目標を検出 するためにはクラッタやレーダ受信 機雑音の性質を統計的に把握する必 要がある。クラッタやレーダ受信機 雑音の除去の方式としてLOG／ CFAR方式がよく知られている。この 方式はレイリ一分布の性質を利用し、 平均值によってクラッタレベルを規 格化し、クラッタの実効值を受信機 雑音の実効值レベルまで抑圧しょう とするものである。ところが、クラッ タやレーダ受信機雑音の確率分布は レイリー分布の他、ワイブル分布、対 数正規分布, $\mathrm{k}$ 一分布等多〈の分布が 知られており、これらの分布はLOG／ CFAR方式では誤警報確率が一定に

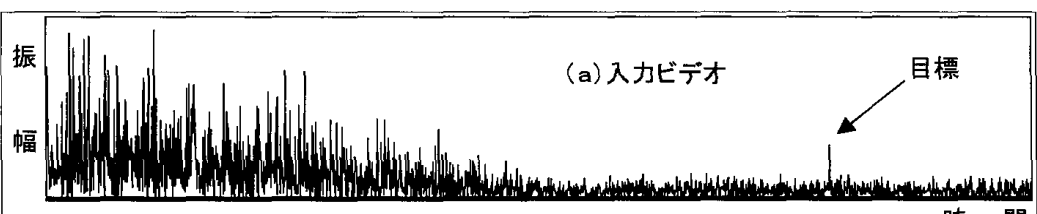

時 間
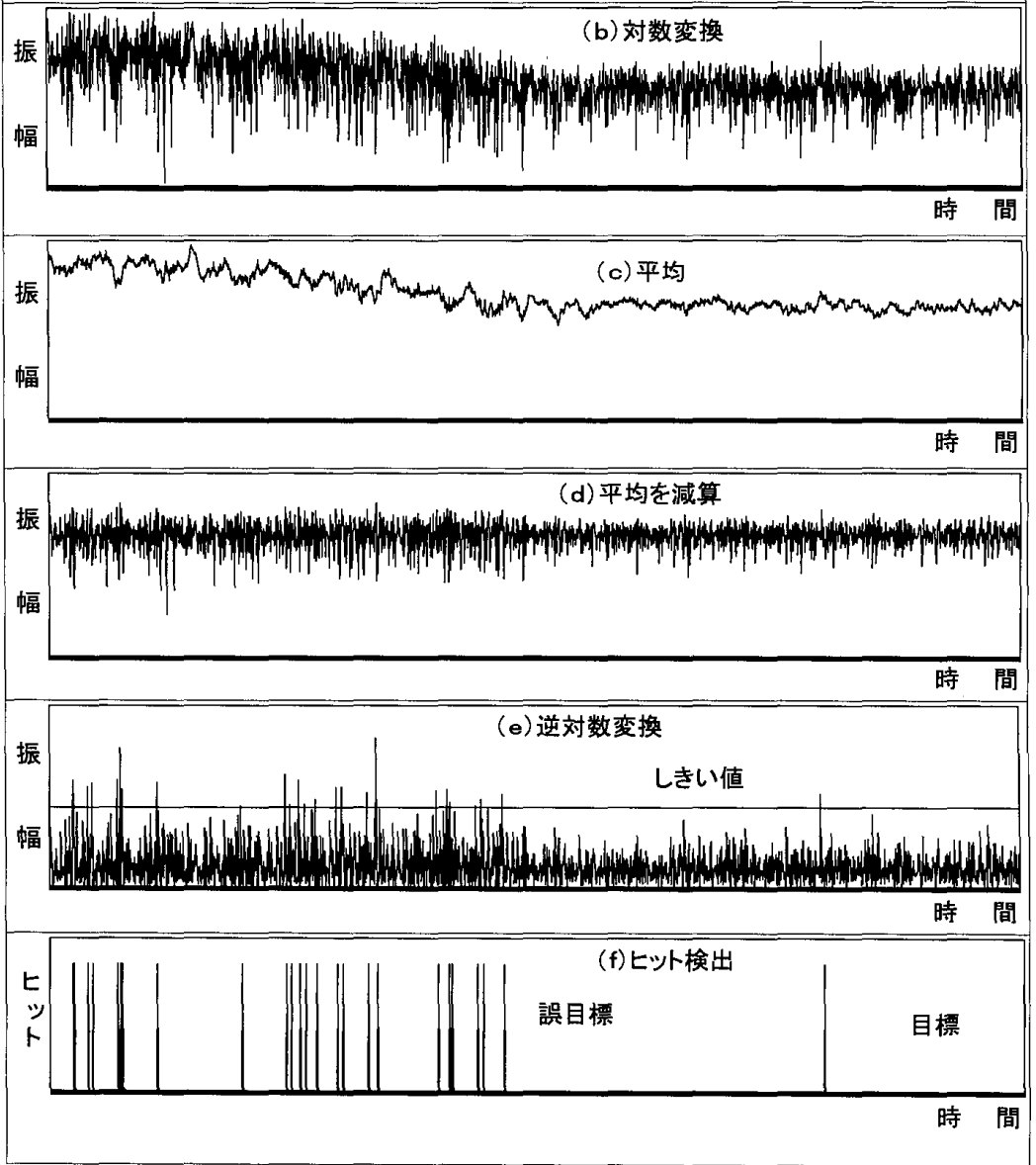

図 1 従来のLOG／CFAR回路動作(ワイブル分布) ならない。図1にワイブル分布の入カビデオをLOG／CFAR方式で処理したシミュレーションを示す。入 力ビデオ(a)を対数増幅器により対数ビデオ(b)に変換し、この対数ビデオから平均(c)を算出し、対数ビデオ (b)からこの平均を減算し(d)、逆対数変換 $(\mathrm{e})$ を行う。次に目標検出のためしきい值を設定し、しきい值を越 えるものをヒットとして検出する。この(e)のビデオはCFAR化されていないため、目標検出のためしきい值 を設定するとその設定レベルによっては(f)に示すように偏在して多くの誤目標を生ずることとなる。この ため、これらの分布に対応したCFAR方式が多く提案されている。特に、ランドクラッタ、シークラッタ、 シーアイスクラッタ、ウェザークラッタがワイブル分布に従うことが報告され、これに対応したCFAR方式 が多く紹介されている(1)。これらは信号の平均值とともに分散を求め、この両者で信号を規格化しようとす るものであるが、これらを構成しょうとすると回路構成が大規模で高速な動作を必要とする難点があった。

\subsection{2 しきい值設定方法の改善}

しきい值設定方法について回路構成が大規模になることなくクラッタやレーダ受信機雑音の確率分布が レイリー分布以外の場合でも対応可能となるよう検討した。

レーダビデオ信号のS / N比を向上させるためにDouble Loop Integratorにより方位積分を行い、次の方 法によりしきい值を求めた。従来より提案されているワイブルCFAR方式で求めている分散の代わりに、標 準偏差に相当する值として振幅值のばらつきを示す偏差を求めることとし、平均 $N$ と偏差 $D$ の值にそれぞ れ乗数 $K 1 、 K 2$ を乗じてしきい值 $T H$ とすることとした。 $K 1 、 K 2$ は誤警報確率を決定する乗数である。 
このしきい值を積分ビデオと比較し 積分ビデオがしきい值を越えるもの を検出する。これはクラッタやレー ダ受信機雑音を含んだ信号を平均の みならず偏差によっても規格化した ことと同等の効果をねらったもので、 クラッタの分布によらずCFAR化を達 成した目標検出を行まうとするもの である。上記(1)式を実現する回路構 成を図 2 に示す。平均および偏差を 求める方法は Cell-Averaging LOG /CFAR回路を応用した。図 2 において、振幅値から平均を減算し、 その差分を絶対值に変換しタップ付 きの遅延回路に入力する。このタッ プ付きの遅延回路の中央の値を除い て各タップ出力の和をつくり、その 值をタップ数で除算を行うことによ $り$ 中央の值に対応する偏差 $D$ を算出 することができる。すなわち信号の ばらつきの移動平均を偏差として求 めたものである。タップの時間間隔 はレーダの送信パルス幅より小さく ならないよう設定し、タップ数は 16 とした。

2.1.3 シミュレーションによる 動作検証

シミュレーションにより動作検証 を行った。

(1) 波形シミュレーション

ワイブル分布の入力ビデオをこの 方式で処理したシミュレーションを 図 3 亿示す。入力ビデオを対数変換

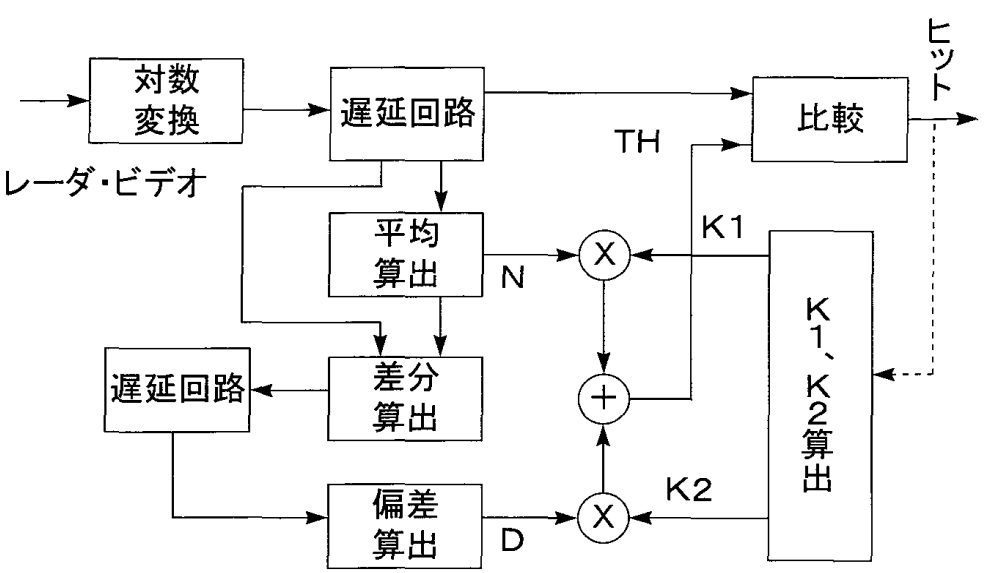

図 2 しきい值算出／ヒット検出回路

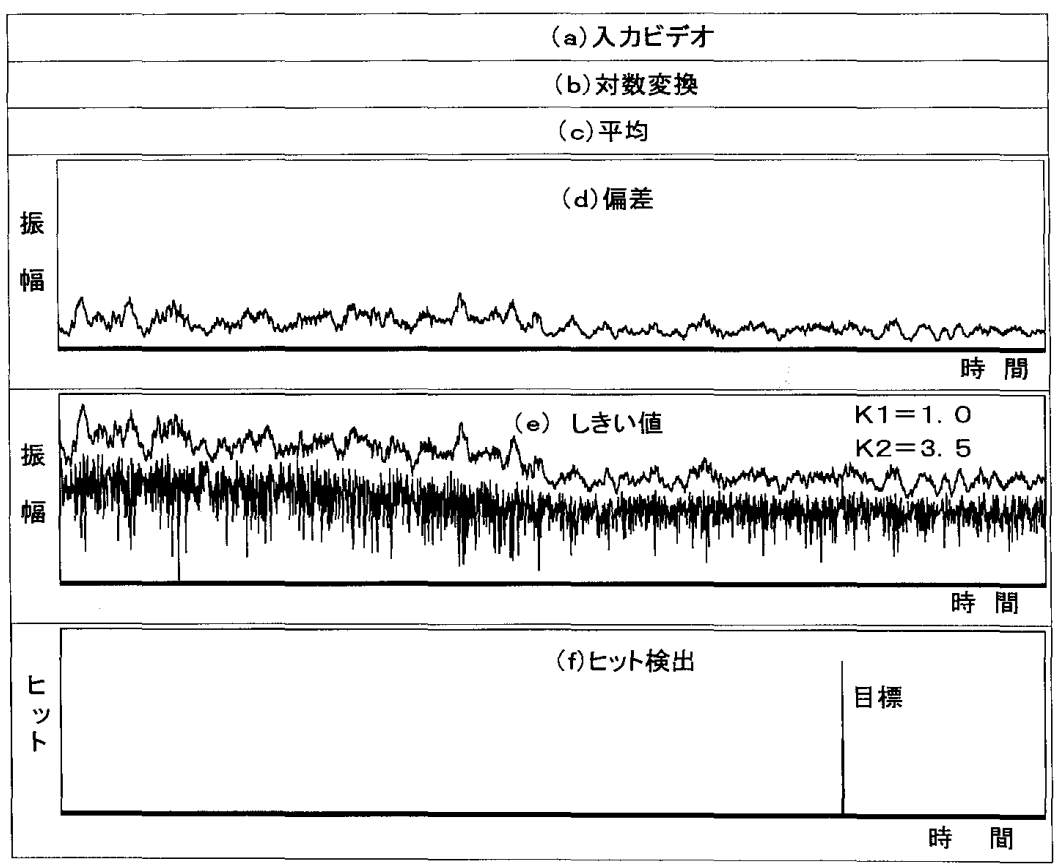

図 3 新方式動作（ワイブル分布） し平均を求める処理までは图 1 の(a) から(c)に示した処理と同一であるので省略する。次に上で述べた方法で求めた偏差を(d)に示す。平均(c)及 び偏差(d)からしきい值を求め対数ビデオと合わせて示したのが(e)である。対数ビデオにしきい值がうまく 適合しヒットを良好に検出している(f)。

(2) ワイブル分布のパラメータと $K 1 、 K 2$ の関係

ワイブル分布の確率密度関数を次に示す(1)。

$$
\begin{array}{r}
P_{c}(x)=\frac{c}{b}\left[\frac{x}{b}\right]^{c-1} e^{-\left(\frac{x}{b}\right)^{c}} \\
(x>0, \quad b>0, \quad c>0)
\end{array}
$$

ここでbは尺度パラメータであり、cは形状パラメータである。 $c=1.0$ の場合は指数分布、 $c=2.00$ 場合 はレイリー分布となる。シークラッタの観測データとしてcの值は1.0から2.00間の值か報告されている(1)。

ワイブル分布の形状パラメータであるcの值を変化させたときの一定誤警報確率が得られる $K 1 、 K 2$ の值

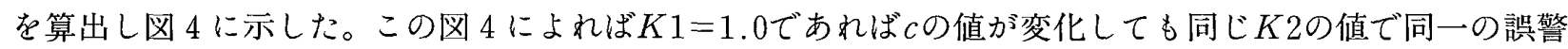
報確率が得られることがわかる。 $K 1 \neq 1.00$ 場合はcの値が変わると $K 2$ の值をそれに対応させて変更しな 
いと一定誤警報確率を保つことがで きない。したがって、K1の值は $1.0 、$ $K 2$ の值は所望の誤警報確率が得られ る值に設定する。

レイリー分布ノイズの場合 $(c=2)$ の $K 1 、 K 2$ の值と愦警報確率の関係 を求め図 5 に示した。

(3) 実データによるシミュレーション 実際に収集したレーダビデオ信号 を用いたシミュレーションを次に示 す。1994年 7 月神奈川県横須賀市追
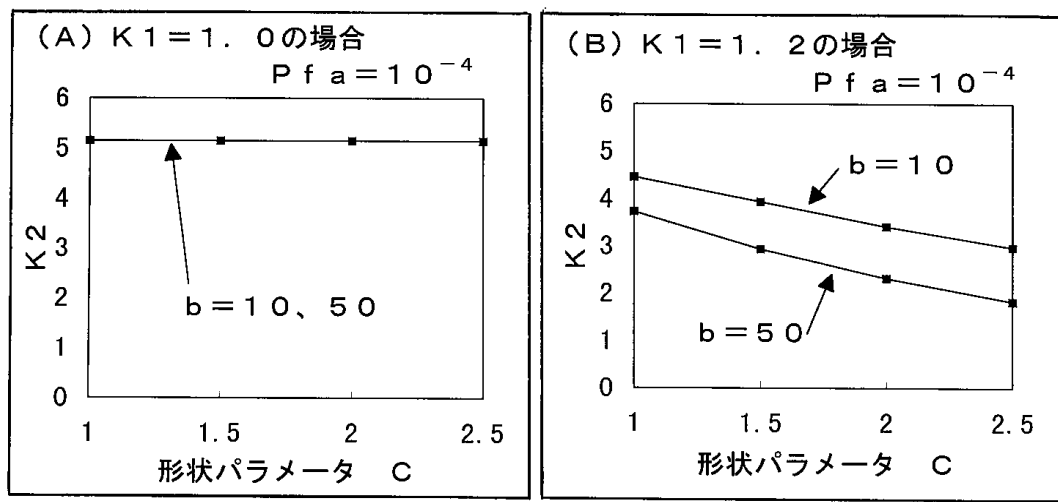

図4 ワイブル分布のパラメータと $K 1 、 K 2$ の関係 浜で収集した東京湾のレーダ・ビデ オ・データを図 6 に示す。そのヒット検出のシミュ レーション結果を図 7 に示す。これら両図を並べて みると図 6 の(1)の目標が検出されていないことがわ かる。これは当該目標の距離方向の前後に大きな目 標が存在しているため、周辺のしきい值が上昇した 結果である。

複数の目標が近接して存在する場合しきい值が急 激に上昇し両者とも検出されにくくなることを防ぐ ため、次の処理を加えて再度シミュレーションを行 った。しきい值算出に用いるビデオ振幅值の上限值 を設定し次の変換を行う。入力されたビデオ振幅值 を $a_{i n}$ 、しきい值算出に用いるビデオ振幅值を $a$ とすると

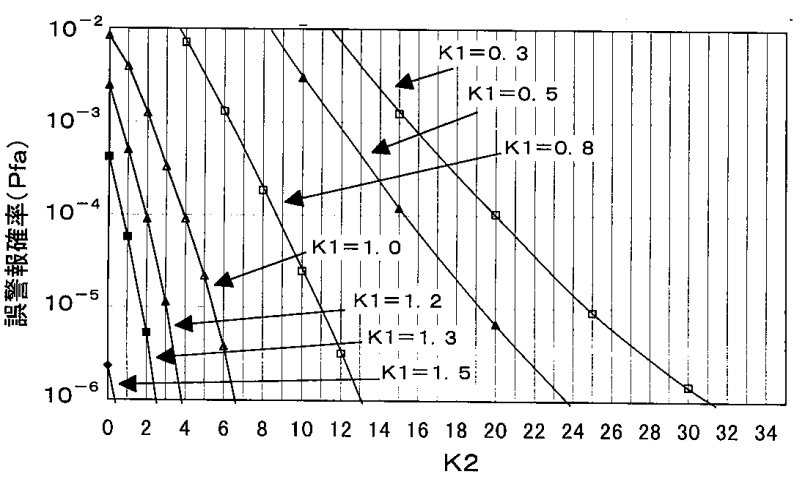

図 5 しきい値乗数 $K 1 、 K 2$ 誤警報碓率 $(\mathrm{Pfa})$ の関保

$$
\begin{aligned}
& a_{i n} \leqq \text { (リミット值) } の \text { 時 } a=a_{i n} \\
& a_{i n}>\text { (リミット值) の時 } a=\text { (リミット值) }
\end{aligned}
$$

ここで、振幅分布の状況を観測し、いくつかの値で（リミット值）を設定したときの効果を確認した。

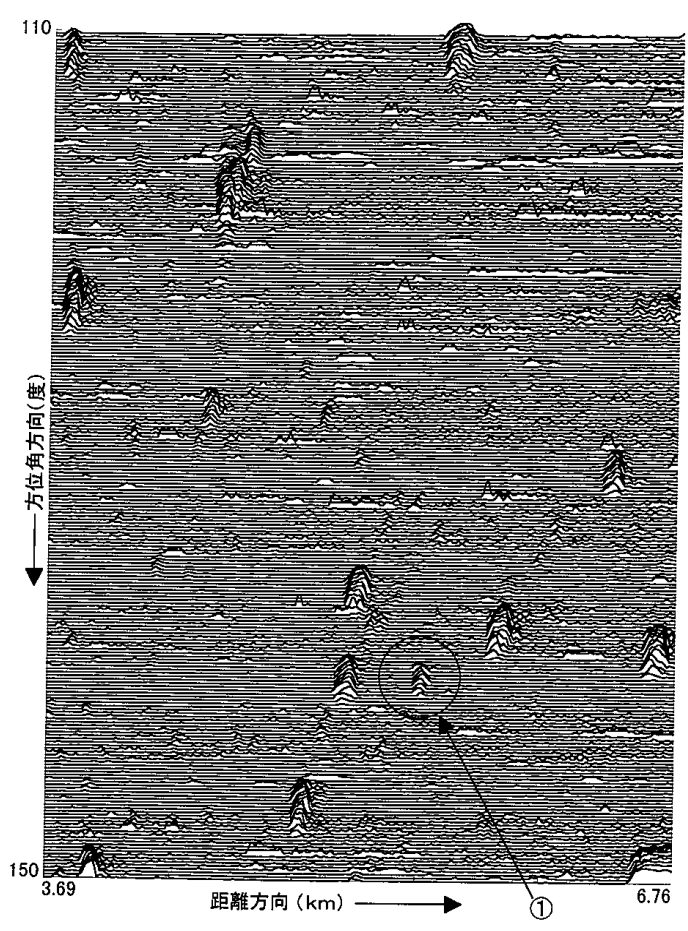

図 6 入力レーダビデオ図

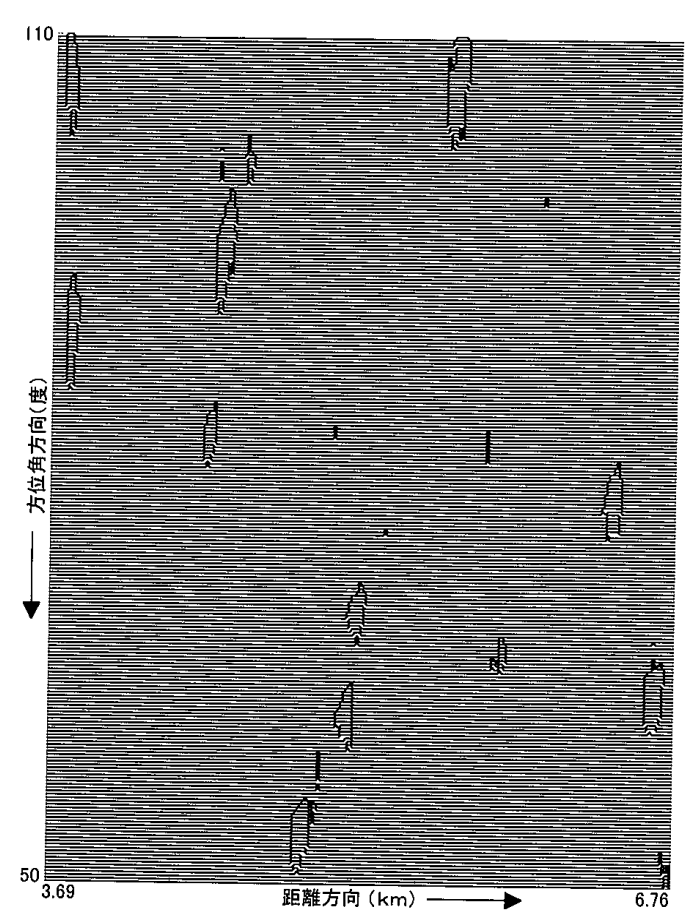

図 7 ヒット検出図 
ビデオの振幅值全体は 0 ～255までの256段階で表現して いるが、(リミット值)を64に設定したシミュレーション の結果が図 8であり、上記の目標(1)が検出されているこ とがわかる。ただしこのように一定のリミット值を設定 するとクラッタに対するしきい值の追従性を鈍くするの で、ビデオの状況に自動的に適応した最適なリミット值 が設定できるようにすることが必要であり今後の課題で ある。

\section{2 目標検出範囲の設定}

䛤来のARPAの他船追尾処理可能数は20隻から40隻程 度のものが多い。日本沿岸を航行する船舶の周囲12NM以 内にはこの追尾処理可能数を超えた多数の船舶が存在す ることが少なくない。ある他船が自船と衝突の可能性が ある場合でも追尾処理を行っていなければ危険性を発見 することはできず、その他船の存在を自船の乗組員に知 らせることができないので危険な事態を招くこととなる。 このためできる限り他船監視上重要度の高い目標の捕捉 追尾を行い、重要度が低くなれば追尾の解除を行う目標 検出領域設定の機能を設けた。これは追尾可能隻数が限 られているため自船に近い目標や自船進行方

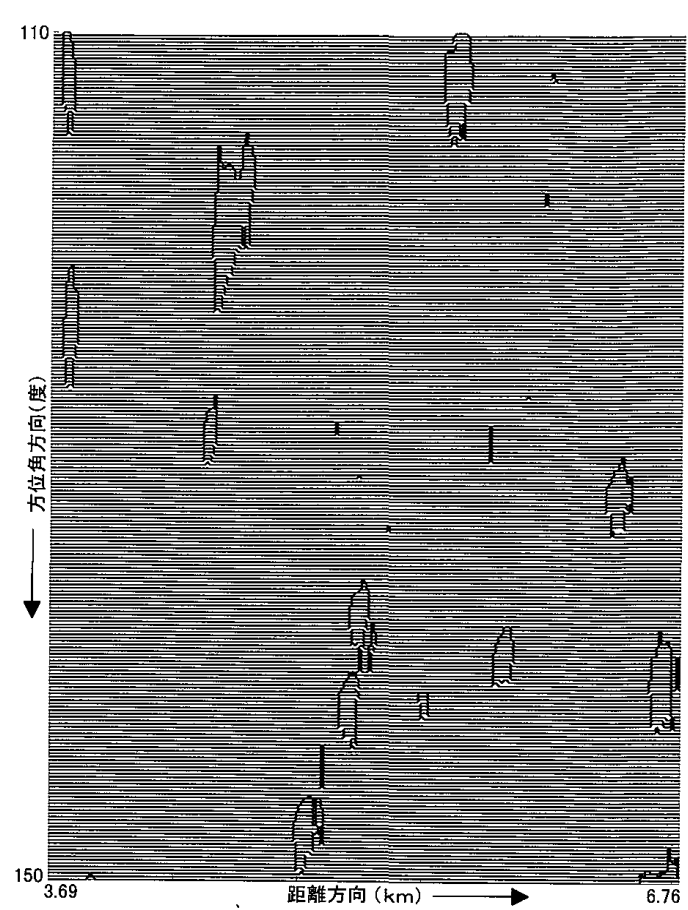

四 8 ヒット検出図 向にいる目標を重要な目標として必ず検出し 重要度の低い目標の捕捉追尾は行わないこと を領域設定することにより実現させるもので ある。

（1）自船が停止している場合や周囲に目標が 少ない場合

自船が停止している場合の目標検出領域は 図 9 (A)に示すように自船を中心とした半径 $\mathrm{C} の$ 円内とし、この範囲内の船舶を検出するもの とする。自船の安全のためにレーダで監視す る領域は前方に限らず全方位でなくてはなら ない。自船に近づく船舶が存在する可能性は

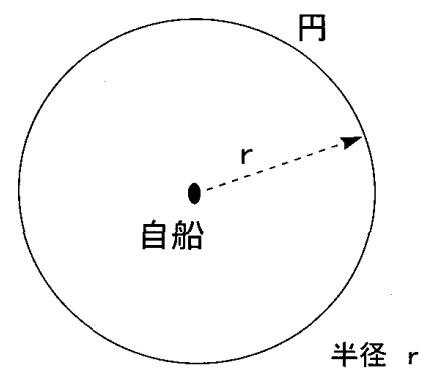

(A) 自船が停止している場合や 目標が少ない場合

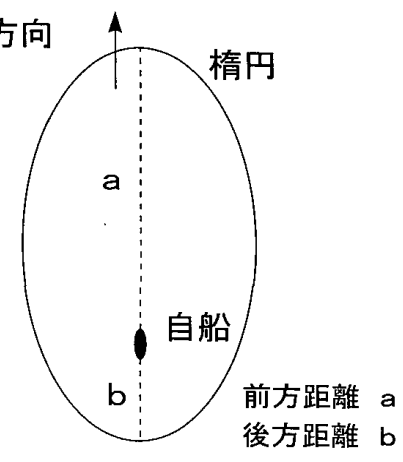

(B) 自船が前進している場合 $360^{\circ}$ いずれの方向にもあるからである。半径 $\mathrm{r}$ は他船を検出する範囲であり、通常レーダの 諸元及び運用上必要十分な值に決めるもので

図 9 目標検出範囲 により目標検出範囲内にある船舶数を追尾処理可能数以下にすることができ、自船から距離 $\mathrm{r}$ 以内にいる船 舶すべてを追尾監視することができる。この領域内の船船が領域外に出た場合はその船舶の検出が行われ ず、その結果追尾が解除される。

この領域設定はまた自船が前進している場合であっても周囲に目標が少ない場合にも有効である。

(2) 自船が前進している場合

自船が前進している場合衝突予防として監視すべき他船を検出する領域は全方位均一でなく進行方向に より大きな面積が必要である。設定する領域の形状は図 9 (B)に示すような楕円またはその他の形状とする。 (1)の場合と同様、船舶数が追尾処理可能隻数を越える場合検出範囲を小さくすることによりこの範囲内の 船舶すべてを追尾監視することが可能となる。この領域内の船舶が領域外に出た場合はその船舶の検出が 行われず、その結果追尾が解除される。

2.3 電子海図によるランドクラッタの処理 
レーダビラ゙オ信号の中には船舶目標からの反射 波以外に陸地、海面、雲などの不要なクラッタも 含まれる。従来よりレーダ信号処理技術によりで きるだけクラッタを目標として検出しないように 処理を行い船舶目標だけを検出しようとしていた。 そころが船舶目標からの反射波とクラッタとの区 別は難しいことが多く、ランドクラッタも目標と して検出することが多かった。ランドクラッタの 処理にはこれまでにもいくつかの方式が提案され 実施されてはいるが、従来のレーダ信号処理技術 だけでランドクラッタを目標として検出しないよ うに処理を行うことには限界がある。今回、電子

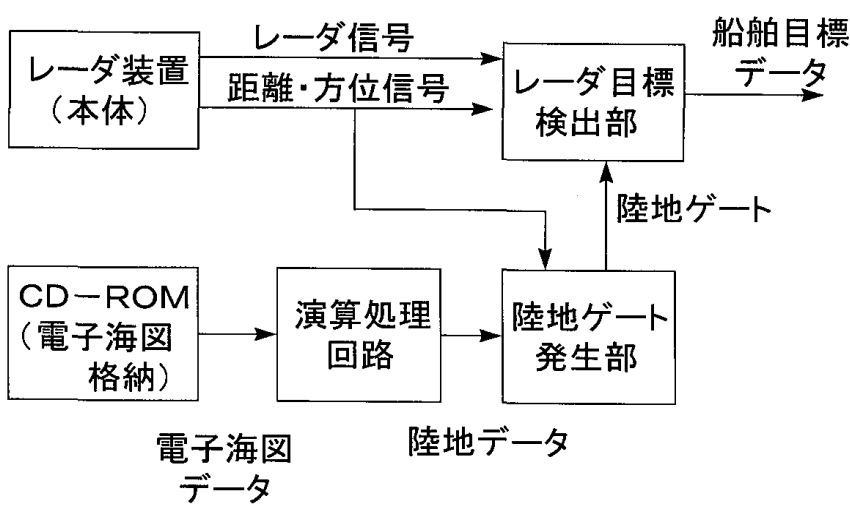

図10 電子海図データ利用によるランドクラッタ処理 海四のデータを利用することによる新しいランド クラッタ処理機能を検討した。図10に示すように、レーダ目標検出部の他に、電子海図が格納されたCDー ROMドライブ、電子海図を読み出す演算処理回路および陸地ゲート発生部を設ける。陸地ゲート発生部は $\mathrm{CD}-\mathrm{ROM}$ から読み出された電子海図データを基にしてレーダビデオ信号と同期させて陸地位置に陸地ゲー 卜信号を発生し、レーダ目標検出部では陸地ゲート信号が発生している距離期問は目標の検出を禁止した。 このことにより陸地領域からの反射波を目標として検出することをなくすことが可能となる。

\section{3. 実験結果と光の考察}

以下に 2. 章に示した機能の実験結果とその考察を示す。

3.1 しき值算出方式について

(1) 目標検出状況

1995年12月 1 日に東京商船大学練習船汐路丸で東京湾浦賀水道北上中に収集したレーダビデオ波形を図 11に示寸。この図の中央付近に多くの船舶の波形が確認できる。右上部と中央下広く突き出ている領域が

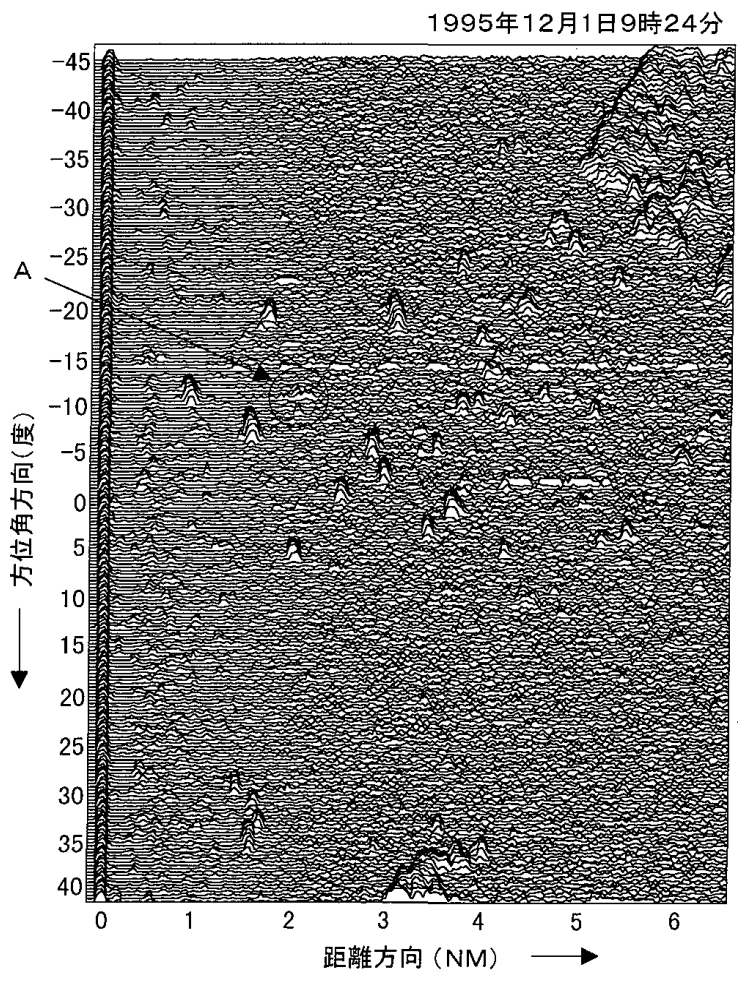

図11 入力レーダビデオ波形図

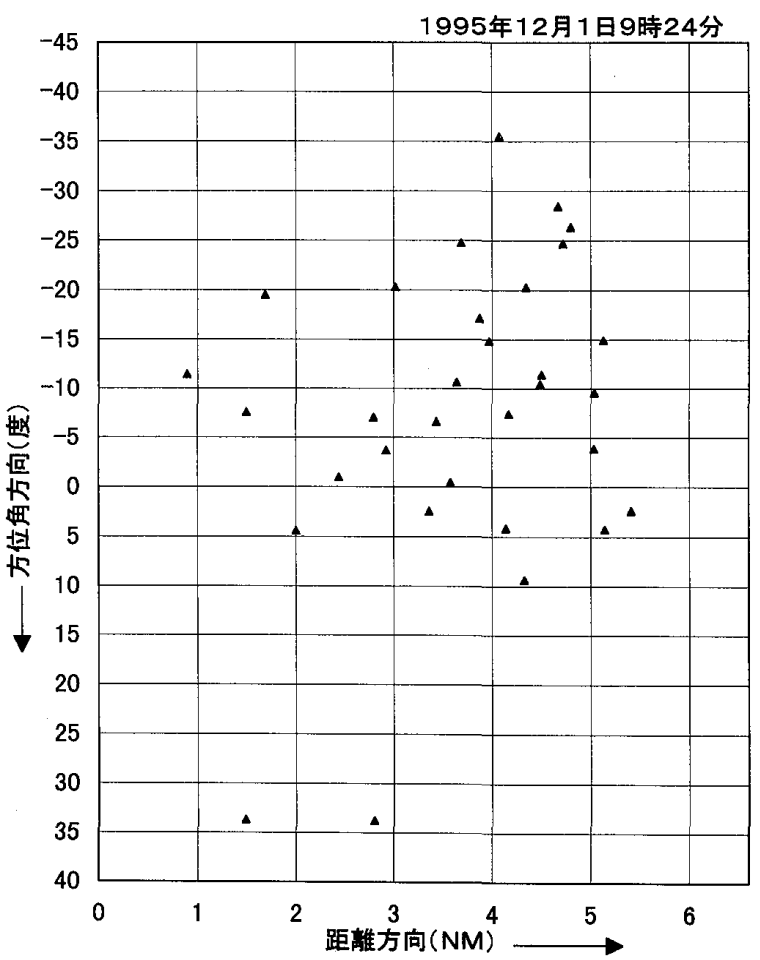

図12 プロット出力分布図 
陸地からの反射によるものである。网12はこのレー ダビデオ信号から目標検出した結果をプロットした ものである。これら両図を㫫べてみると、陸地から の反射信号を目標として検出することがなく、また、、 中央付近の船舶からの反射信号とプロットの位置は 正確に一致していることがわかる。困11のAは目標 であるが、目標の振幅が受信機雑音と同レベルまで 低く図12では目標として検出されていない。

（2）設定パラメータについて

しきい值算出に用いられるパラメータ $K 1 、 K 2$ は 次の值を使用した。

\section{$K 1=1.0 \quad K 2=11.5$}

2.1節で述べたようにK1の值は 1.0 とし、K2の值 は1 スキャンあたりに生じる鿁目標数が平均して50

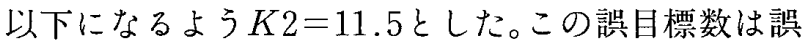
警報確率が約 $5.0 \times 10^{-4}$ に相当し、シミュレーション で求めた図 5 によると、K2=11.5の場合の誤警報確 率は $1.0 \times 10^{-6}$ 以下であり、大きく異なってしまった。 これはレーダビデオに含まれる受信機雑意がベース ライン下に沈み込んでいる領域があり、そこでは平 均 $N$ や偏差 $D$ がさくなりその結果 しきい值が小さくなって多くの鿁目 標が検出されやすくなったため $K 2$ の 值を大きくする必要があったこと等 によるものである。実際のレーダビ デオ振幅の密度や振幅はいろいろな レーダごとに状況が異なると考えら れるので、それらのレーダと接続さ れた時点でK $K 2$ 值を設定する必要が ある。

（3）検出結果について

目標検出率や検出データの精度を 評価するため振幅の小さな目標とし て図11の中の目標Aについて分析し た。同日9時23分から31分までに検 出された目標をプロットしたものを 四13に示す。この目標 $\mathrm{A}$ について検 出距離と検出方位の時間経過に伴う 変化をプロットし、それぞれ最小二 乗曲線を求め図14および図15に示し た。その曲線が真の距離、方位を示 すものと仮定し、この曲線の対応す る值と各距離值、方位值との差を䛊 差とし最大䛊差と標準偏差を算出し t。

距離については最大誤差は0.05 NM、標準偏差は0.01NMであった。

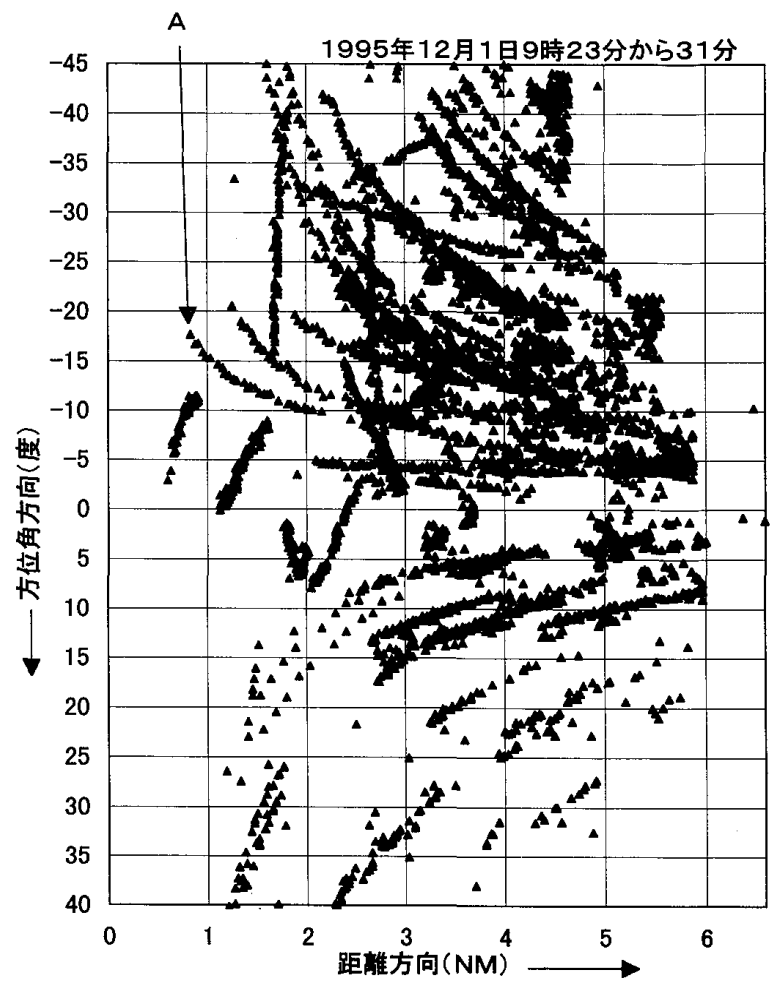

図13 プロット出力分布図

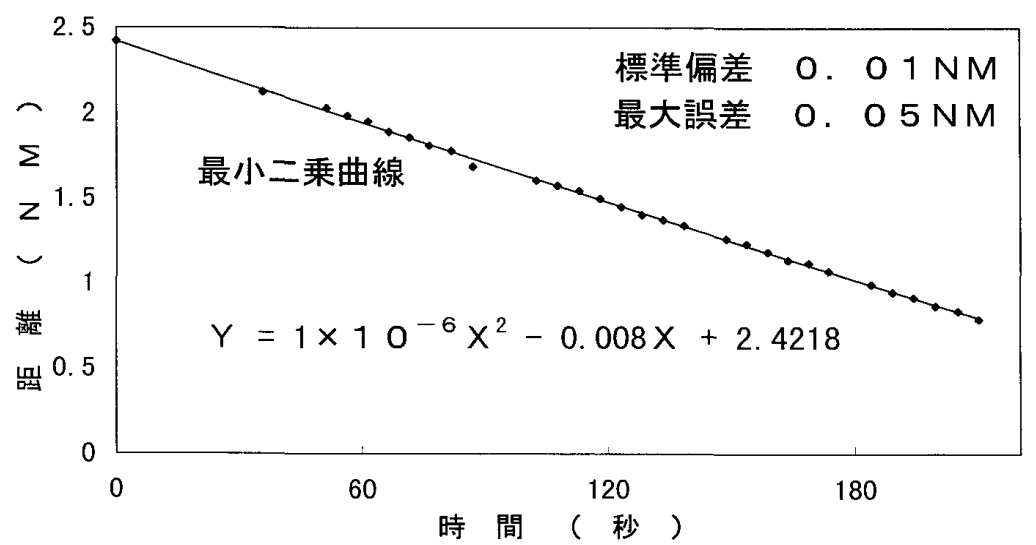

図14 目標Aの距離の変化

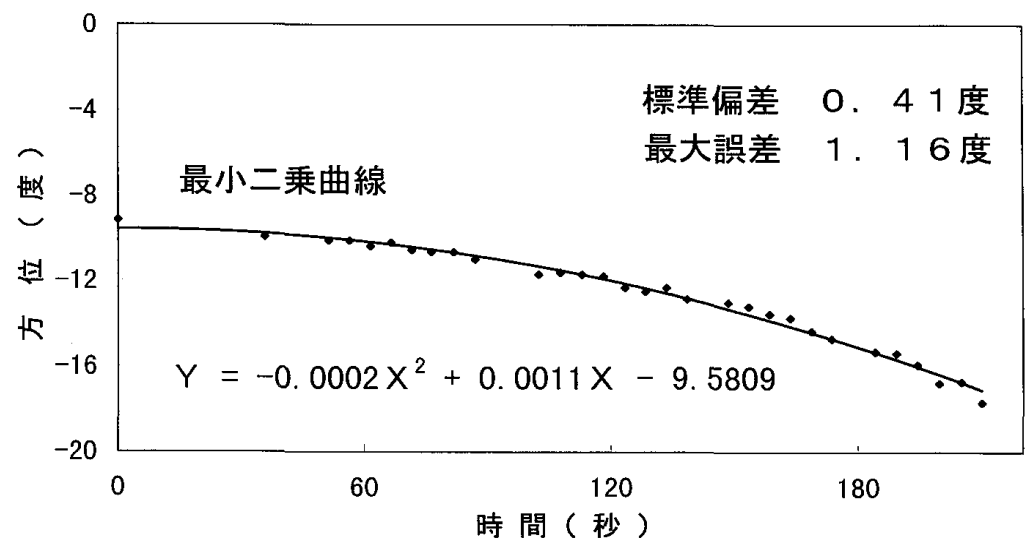

図15 目標Aの方位の変化 
標準偏差値が $0.01 \mathrm{NM}$ と小さく、これは目標検出機能部における距離の最小基本単位 $(1 / 64 \mathrm{NM}=0.015625$ $\mathrm{NM}$ ）とほぼ等しい。距離の誤差は非常に小さく良好といえる。

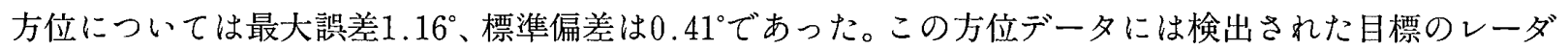
方位角に自船の向いている方位を示すジャイロコンパスからの方位角も加算されているためその誤差も含

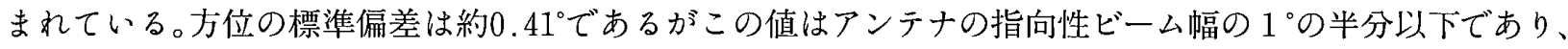
目標検出結果の值としては妥当であると考えられる。

(4) 目標検出率について

目標検出率は時々刻々変化する周囲の環境により変化するため算定することは難しい。図13の目標 Aの 検出状況を調査した結果、32 スキャン中 28 回検出と全体的にほぼ安定して検出されている。この検出率は 目標追尾処理を行うのに十分な值である。

3.2 目標検出範囲指定について

目標検出範囲は次の 6 種類とし、手動設定により切り替え可能にして実験を行った。

(1)円 $\mathrm{r}=6 \mathrm{NM}$ (2)円 $\mathrm{r}=12 \mathrm{NM}$ (3)円 $\mathrm{r}=24 \mathrm{NM}$ (4)棈円 $\mathrm{a}=6 \mathrm{NM} \quad \mathrm{b}=2 \mathrm{NM}$ (5)楕円 $\mathrm{a}=12$ $\mathrm{NM} \quad \mathrm{b}=4 \mathrm{NM}$ (6)楕円 $\mathrm{a}=24 \mathrm{NM} \quad \mathrm{b}=8 \mathrm{NM} \quad$ ( $\mathrm{a}$ は前方距離、 $\mathrm{b}$ は後方距離)

目標数が多くなれば目標検出範囲を棈円にしたり、範囲を小さくしたりすることにより、自船前方の監 視領域を広くとりながら不必要な遠距離の船舶目標の処理を行わないように設定して船上試験を行い、本 機能が非常に有効であることが確認された。ただし、最小の領域である上記の(4)を設定してもその領域内 に存在する船船数が追尾処理可能数 40 より多いことがあった。船舶数が追尾可能隻数をこえる場合は追尾 監視をしていない目標が目標検出範囲内に存在する。衝突予防の観点からは目標検出範囲内の船舶数が追 尾可能隻数をこえる事態にさせないことが重要であり、その対策として追尾処理可能数の増加および実験 で示した目標検出範囲をさらに小さく設定可能とするなどの領域の形状や大きさの検討が必要である。

また、自船速度を変えて設定する例として速度が 0 の場合と速度を持って前進している場合の 2 例を示 したが、速度の高低による最適な領域の形状や大きさの検討も今後の課題である。

領域の拡大・縮小、形状の変更については、自船速度や他船目標数に応じて自動的に行うのが有効であ る。

3.3 電子海図によるランドクラッタの処理について

図11、図12を並べてみると陸地からの反射信号を目標船舶として検出寸ることがなく、電子海图による ランドクラッタ領域の目標検出禁止機能が有効であることがわかる。ただし陸地位置データの更新が 6 分 間隔であったため自船移動中は検出禁止領域とレーダビデオのランドクラッタの位置とが徐々にずれる場 合があった。陸地位置データの更新時間はさらに短くする必要がある。

\section{4. まとめ}

ARPA機能を向上させる方策として、3つの方法を提案した。

(1) しきい值算出方式は従来型LOG／CFAR方式を発展させたもので、レーダ受信ビデオの分布の種類に よらず、誤警報確率を一定にすることを目標としたターゲット検出方式の効果が検証された。まだ検討 や改良すべき事項があるが、実船試験において良好な結果を示した。

(2) ARPA機能はレーダ目標を検出追尾し他船との衝突の危険性を事前に検出する機能であり、衝突予防 の観点から重要な目標は必ず追尾処理することが必要である。ところが追尾処理可能数は限られている ため従来のARPAは衝突予防の観点からの重要な目標の追尾処理が行えないことがあった。本方式は目 標検出領域を設定することにより近距離の目標や自船進行方向にいる重要な目標は必ず追尾処理するこ とを実現させたものであり実際の試験においても有効性が実証された。今後のARPA機能において非常 に有効な機能と考えられる。ただし目標検出領域の設定方式、形状や大きさの最適化や自動化について はさらに検討を行う。

（3）電子海図と連動させて陸地領域からの目標検出を禁止する機能は、陸地からの反射を船舶と認識して 陸地領域内に船舶目標シンボルを表示してしまうことや、陸地からの反射による目標が多数追尾処理さ れていると追尾処理可能数が限られているため実際の船舶の追尾処理ができず目標シンボルの表示も衝 
突の危険性の検出もできないことを防止するものであり、実際の試験においても有効性が実証された。 ECDIS とARPAが組み合わされて使用される場合きわめて有効な機能である。

\section{謝 辞}

本研究開発はモーターボート競争公益資金により日本財団の援助を受けて（財）シップ・アンド・オー シャン財団（会長 今関憲作）が行う技術開発基金による補助金を受けて平成 5 年度から平成 7 年度の 3 年間にわたり実施したものである。ここに深く感謝申し上げます。また、レーダ信号処理方式につい てご助言をいただきました東京工業大学関根松夫助教授に厚くお礼申し上げます。

\section{参 考 文 献}

（1）関根松夫：レーダ信号処理技術，pp.108-pp.130，電子情報通信学会，平成 3 年 9 月 20 日

\section{質 疑 応 答}

佐藤尚登（海技大学校）：ロウ・ビデオを対数変換した後の信号処理について、しきい值をエコーレベルの 関数によって求めたということですが、対数变換した後のエューでは飽和に近い信号と非常に弱い信号 での偏差では大きな差異があると思います。そこで、次の点について教えてください。(1)飽和に近いエ コーすなわち非常に強い受信信号での $K 1 、 K 2$ の值と非常に弱い信号での $K 1 、 K 2$ の值に違いはありま せんでしょうか。(2) $K 1 、 K 2$ の值を手動入力したとのことですが、受信信号レベルの違い等で $K 1 、 K 2$ の入力值に何か特性があれば教えてください。

小塚孝徳：一般にレーダ・ロウ・ビデオは信号レベルが高い領域では分散も大きいため対数変換した後、 信号レベルの高い領域の偏差と低い領域の偏差とに大きな差異が生ずるとはいえず、逆に差異を小さく させるものです。レイリ一分布の場合は対数変換をすると信号レベルの高い領域も低い領域も偏差が同 に゙になります。本論文では、ワイブル分布のように対数変換をしても偏差が一定にならない場合でも対 応可能としたもので、しきい值を平均と偏差の関数にしたことにより、 $K 1 、 K 2$ は信号レベルの高い領 域でも低い領域でも同じ值を適用することが可能となります。

水城南海男（電子航法研究所）：(1)レーダのGAIN、STC、FTC等の状態をどのように仮定したロウ・ビデ オですか。(2)測定したロウ・ビデオは、ぼのような条件（レーダの運用状態）でしたか。

小塚孝徳：(1)航海士が通常行うレーダの運用設定の範囲内で使用される事を想定しています。(2)測定時は PPI表示が見やすいようGAINを調整し、STCを設定しておりました。 